\title{
Motivasi Ibu dalam Pemberian ASI Eksklusif pada Bayi : Literature Review
}

\author{
Maulida Yulianti ${ }^{1 *}$, Ratnawati $^{2}$ \\ ${ }^{1,2}$ Program Studi Sarjana Keperawatan, Universitas Muhammadiyah Pekajangan Pekalongan, \\ Indonesia \\ *email:maulidayulianti013@gmail.com
}

\begin{abstract}
Breast milk is the main source of nutrition for babies who many benefits. Exclusive breastfeeding is highly recommended to mothers who have babies aged 0-6 months. The mother needs motivation in the success of giving exclusive breast milk. Breastfeeding motivation is the motivation, advice, and decision to give breast milk. The purpose this study aims to find out the motivation of mothers in exclusive breastfeeding in infants through literature review. The method used is descriptive design, data collection method literature review and used 5 articles from database with electronic search on Garba Garuda and Search Engine published in 2012-2021. The result of this study showed that $358(58 \%)$ respondents had high motivation and 259 (42\%) respondents was low motivation. The conclusion of this study respondents who had more high motivation than respondents who had low motivation. The higher the motivation of a mother, the higher the mother will also give exclusive breast milk to her baby.
\end{abstract}

Keywords: mother breastfeeding; exclusive breastfeeding; motivation

\begin{abstract}
Abstrak
Air susu Ibu merupakan sumber nutisi utama bagi bayi yang memiliki banyak manfaat. Pemberian air susu ibu secara eksklusif sangat dianjurkan bagi ibu yang memiliki bayi usia 06 bulan. Ibu memerlukan motivasi dalam keberhasilan memberikan ASI eksklusif. Motivasi menyusui merupakan dorongan, nasihat, dan keputusan untuk memberikan ASI. Tujuan pnenelitian ini bertujuan untuk mengetahui motivasi ibu menyusui pada bayi melalui literature review. Metode yang digunakan yaitu desain deskriptif, metode pengumpulan data dengan literature review dan menggunakan 5 artikel dari database dengan penelusuran elektronik di Garba Garuda dan Search Engine yang dipublikasikan pada tahun 2012-2021. Hasil penelitian menunjukkan bahwa $358(58 \%)$ responden memiliki motivasi tinggi dan 259 $(42 \%)$ responden memiliki motivasi rendah. Simpulan penelitian ini responden yang memiliki motivasi tinggi lebih banyak daripada responden yang memiliki motivasi rendah. Semakin tinggi motivasi seorang ibu maka semakin tinggi pula ibu dalam memberikan ASI eksklusif pada bayinya.
\end{abstract}

Kata kunci: Ibu menyusui; ASI eksklusif; motivasi

\section{Pendahuluan}

Air Susu Ibu merupakan sumber nutrisi bagi bayi selama 4-6 bulan dan sebagai perlindungan bagi si bayi dari penyakit diare. Air Susu Ibu juga sebagai sumber kebutuhan gizi yang penting bagi kesehatan bayi dan juga sebagai sumber protein yang dibutuhkan bayi ketika umur 6-12 bulan. Pemberian air susu ibu ekslusif selama 6 bulam merupakan investasi terbesar karena banyak manfaat yang diperoleh dari ASI. Manfaat dari pemberian ASI yaitu dapat menciptakan generasi yang memiliki intelegensia, emosi dan spiritual yang baik dibandingkan dengan bayi yang diberikan susu formula[1]. Menurut Kementerian Kesehatan Republik Indonesia, untuk 


\section{Prosiding Seminar Nasional Kesehatan $\mathbf{2 0 2 1}$ Lembaga Penelitian dan Pengabdian Masyarakat Universitas Muhammadiyah Pekajangan Pekalongan}

mengurangi risiko kematian pada bayi maka pemberian ASI eksklusif perlu dilakukan karena ASI eksklusif mengandung kolostrum yang dapat membunuh kuman yang ada di dalam tubuh bayi dan sebagai daya tahan tubuh bagi bayi[2].

Presentase data cakupan pemberian ASI eksklusif menurut World Health Organization (WHO) tahun 2015 di Asia Selatan sebesar 47\%, Amerika Latin dan Karibia sebesar 32\%, Asia Timur sebesar 30\%, Afrika Tengah sebesar 25\%, dan negara berkembang lainnya sebesar 46\%. Data cakupan tersebut belum sesuai dengan target WHO yaitu meningkatkan pemberian ASI ekslusif kepada bayi baru lahir selama 6 bulan pertama[3].

Secara nasional, pada tahun 2018 cakupan bayi mendapat ASI eksklusif sebesar 68,74\%. Angka tersebut sudah melampui target Renstra tahun 2018 yaitu 47\%. Presentase tertinggi cakupan pemberian ASI eksklusif terdapat pada provinsi Jawa Barat sebesar 90,79\%, presentase terendah terdapat pada provinsi Gorontalo sebesar $30,71 \%$, sedangkanJawa Tengah dengan presentase cakupan pemberian ASI eksklusif sebesar 45,21\%[4].

Menurut penelitian yang dilakukan Reni Merta Kusuma dan Aesti Irawan mengenai motivasi ibu menyusui dalam pemberian ASI eksklusif di wilayah Puskesmas Tegalrejo Yogyakarta dengan 85 responden dapat disimpulkan bahwa sebagian besar ibu menyusui memiliki motivasi tinggi dalam pemberian ASI eksklusif sebanyak 64,7\%[5]. Sedangkan penelitian yang dilakukan Desy Ratna Endriyeni dan Kusuma Estu Werdani mengenai motivasi pemberian asi eksklusif oleh ibu di Puskesmas di Kabupaten Boyolali dengan 224 responden dapat disimpulkan bahwa sebagian besar ibu memiliki motivasi rendah dalam pemberian ASI eksklusif sebanyak 52,2\%[6]. Penelitian yang sama juga dilakukan oleh Rahmaliza Harseni di Puskesmas Lapai Kota Padang dengan 53 responden dapat di simpulkan bahwa paling banyak ibu mendapat motivasi dengan tidak baik sebanyak 30 orang 56,6\%[7].

Motivasi dari seseorang ibu diperlukan dalam pemberian ASI secara eksklusif selama 6 bulan. Motivasi baik yang dimiliki oleh seorang ibu maka seseorang ibu akan senantiasa dan selalu berusaha untuk menyusui bayinya.Adanya dukungan dari keluarga terutama dukungan suami maka akan berdampak kepada peningkatan rasa percaya diri atau motivasi ibu dalam menyusui bayinya. Penentu motivasi pada ibu menyusui berasal dari dorongan dari petugas kesehatan dan dukungan keluarga serta dari tempat ibu bekerja yang menjadikan ibu menyusui bayinya[8].

Tujuan penelitian ini untuk mengetahui gambaran motivasi ibu dalam pemberian ASI eksklusif kepada bayi berdasarkan evidence yang tersedia.

\section{Metode}

Peneletian ini menggunakan strategi pencarian literature review yaitu mencari hasil publikasi antara tahun 2012-2021 melalui penelusuran elektronik di Garba Garuda dan Search Engine. Hasil pencarian menggunakan kata kunci "ibu menyusui" and "ASI eksklusif" and "motivasi". Penelitian ini menngunakan kriteria inklusi yaitu artikel yang digunakan sesuai dengn kata kunci, publikasi artikel antara tahun 2012-2021 dengan menggunakan Bahasa Indonesia dan/atau Bahasa inggris, instrumen yang digunakan 


\section{Prosiding Seminar Nasional Kesehatan Lembaga Penelitian dan Pengabdian Masyarakat Universitas Muhammadiyah Pekajangan Pekalongan

dalam artikel cross sectional, dan responden dalam artikel ibu menyusui. Penelitian ini menggunakan telah JBI (Joanna Briggs Institute) Critical Appraisal Checklist for Analitycal Cross Sectional Studies. JBI Critical Appraisal Checklist for Analitycal Cross Sectional Studies adalah daftar periksa yang digunakan khusus penelitian desain cross sectional yang bertujuan untuk mencari hubungan antara 2 variabel atau lebih.Penelitian ini dilakukan mulai bulan Januari 2021.

\section{Hasil dan Pembahasan}

\section{Hasil}

Berdasarkan literature review terhadap 5 artikel diperoleh hasil penelitian berupa data motivasi pemberian ASI Eksklusif, motivasi tinggi sejumlah $358(58 \%)$ responden dan motivasi rendah berjumlah 259 (42\%) responden. Hasil analisa data motivasi pemberian ASI Eksklusif dari lima artikel dapat dilihat pada tabel 1 dibawah ini :

Tabel 3.1 Distribusi frekuensi motivasi dalam pemberian ASI eksklusif

\begin{tabular}{|c|c|c|c|c|c|}
\hline \multirow{3}{*}{$\begin{array}{l}\text { Artikel } \\
\text { Penulis }\end{array}$} & \multicolumn{5}{|c|}{ Motivasi dalam pemberian ASI eksklusif } \\
\hline & \multirow[t]{2}{*}{ Tahun } & \multicolumn{2}{|c|}{ Tinggi } & \multicolumn{2}{|c|}{ Rendah } \\
\hline & & $\mathrm{F}$ & $\%$ & $\mathrm{~F}$ & $\%$ \\
\hline Edite Pinto, et.al & 2016 & 156 & $66,4 \%$ & 79 & $33,6 \%$ \\
\hline $\begin{array}{l}\text { Reni Merta Kusuma, Aesti } \\
\text { Irawan }\end{array}$ & 2018 & 55 & $64,7 \%$ & 30 & $35,3 \%$ \\
\hline $\begin{array}{l}\text { Desy Ratna Endriyeni, Kusuma } \\
\text { Estu Werdani }\end{array}$ & 2020 & 107 & $47,8 \%$ & 117 & $52,2 \%$ \\
\hline Tri Utami L., Venny Vidayanti & 2016 & 19 & $51,4 \%$ & 18 & $48,6 \%$ \\
\hline Wulan Wijaya, dkk & 2019 & 21 & $58,3 \%$ & 15 & $41,7 \%$ \\
\hline Total masing-masing motivasi & & 358 & $58 \%$ & 259 & $42 \%$ \\
\hline Total responden $(n)$ & & & & 617 & \\
\hline
\end{tabular}

\section{Pembahasan}

Berdasarkan hasil literature review dari 5 artikel pada tabel 1 didapatkan hasil bahwa 358 (58\%) responden memiliki motivasi yang tinggi dalam memberikan ASI eksklusif. Semakin tinggi motivasi seorang ibu maka akan semakin tinggi pula ibu dalam memberikan ASI eksklusif pada bayinya. Ibu yang memiliki pengetahuan yang baik tentang pentingnya ASI eksklusif maka seorang ibu memiliki motivasi yang tinggi dalam memberikan ASI eksklusif pada bayinya[5]. Pemberian ASI Eksklusif ini terdapat dalam Al Quran surat Al Baqarah ayat 233 yang artinya "Para ibu hendaklah menyusukan anak-anak mereka selama dua tahun penuh, bagi yang ingin menyempurnakan penyusunan itu". Penyempurnaan pertumbuhan dan perkembangan pada bayi didapat pada pemberian ASI [9]. 


\section{Prosiding Seminar Nasional Kesehatan 2021 Lembaga Penelitian dan Pengabdian Masyarakat Universitas Muhammadiyah Pekajangan Pekalongan}

Hasilpenelitianinisesuaidenganpenelitianyangtelahdilakukan oleh Srigati, dkk (2016) dengan hasil penelitian menunjukkan bahwa responden yang memiliki motivasi tinggi merupakan responden yang terbanyak yaitu 22 responden $(68,8 \%)$. Motivasi tinggi yag dimiliki ibu dipengaruhi oleh pengetahuan yang baik, harapan yang tinggi atau keyakinan yang tinggi serta kemauan yang kuat dalam memberikan ASI eksklusif pada bayinya. Sedangkan motivasi yang rendah dipengaruhi oleh kurangnya pengetahuan yang dimiliki oleh seorang ibu dan faktor dari dukungan keluarga khususnya dukungan dari suami dalam memotivasi ibu untuk memberikan ASI eksklusif pada bayinya [10].Pengetahuan ibu dapat diperoleh dari informasi melalui media elektronik, surat kabar atau informasi dari petugas kesehatan tentang ASI eksklusif. sehingga ibu termotivasi untuk memberikan ASI eksklusif. Pengetahuan juga bisa berasal dari pengalaman ibu menyusui. Ibu yang sudah pernah menyusui atau memiliki anak lebih dari satu akan berpeluang untuk memberikan ASI eksklusif selama 6 bulan dibandingkan dengan ibu yang baru pertama kali melahirkan anak pertama. Ibu yang baru mempunyai anak akan mengalami kesulitan dalam menyusui bayinya. Kesulitan tersebut berupa ASI ibu belum keluar dan ibu belum mengerti bagaimana cara menyusui yang benar. Oleh karena itu, pengetahuan dan pengalaman dapat mempengaruhi motivasi ibu dalam menyusui bayinya.

Motivasi pemberian ASI eksklusif merupakan suatu dorongan, anjuran, dan keputusan untuk memberikan ASI. Tercapainya peningkatan jumlah peningkatan pemberian ASI dapat dipengaruhi oleh motivasi yang baik. Motivasi yang baik diharapkan dapat membantu seseorang dalam mencapai pemberian ASI yang baik sesuai dengan yang diharapkan. Motivasi yang baik juga diharapkan mampu untuk mengatasi hal-hal yang mempengaruhi penurunan pemberian ASI [11].

Berbeda dengan penelitian Maulida, dkk (2015) didapatkan hasil bahwa sebagian besar responden memiliki motivasi dalam pemberian ASI Eksklusif pada kategori sedang sebanyak 21 responden $(43,7 \%)$ dibandingkan dengan responden yang memiliki motivasi tinggi dan rendah. Motivasi tinggi yang dimiliki seorang ibu tidak menjadi suatu jaminan bahwa seorang ibu akan memberikan ASI Eksklusif kepada bayinya, hal tersebut dikarenakan oleh faktor-faktor yang mempengaruhi motivasi ibu dalam memberikan ASI eksklusif diantaranya faktor lingkungan, faktor ini sangat berpengaruh terhadap motivasi ibu dalam memberikan ASI Eksklusif, termasuk dalam faktor lingkungan salah satunya yaitu dukungan keluarga khususnya suami dan faktor ketersediaan fasilitas berupa ruangan pojok ASI disetiap fasilitas umum [10]. Ruang pojok ASI akan memotivasi setiap ibu untuk tetap memberikan ASI Eksklusif kapan saja dan di mana saja. Ruang pojok ASI sangat dibutuhkan oleh ibu menyusui yang bekerja. Oleh karena itu, dukungan yang lebih dari pihak luar seperti manajemen tempat kerja dan lingkungan tempat kerja sangat dibutuhkan bagi ibu menyusui agar ibu dapat memberikan ASI eksklusif kepada bayinya.

Dalam keberhasilan pemberian ASI eksklusif, suami dapat berperan aktif dengan memberi dukungan secara emosional dan perhatian karena motivasi suami sangat berpengaruh terhadap pemberian ASI kepada bayi dan suami merupakan orang terdekat bagi ibu. Ibu menyusui memerlukan kondisi emosional yang stabil karena 


\section{Prosiding Seminar Nasional Kesehatan $\mathbf{2 0 2 1}$ Lembaga Penelitian dan Pengabdian Masyarakat Universitas Muhammadiyah Pekajangan Pekalongan}

kondisi tersebut dapat mempengaruhi produksi ASI [12].Memberikan rasa empati, cinta dan kepercayaan merupakan salah satu bentuk motivasi suami kepada ibu dalam memberikan ASI eksklusif. Bentuk motivasi ini membuat ibu merasa nyaman, yakin, merasa diperhatikan, serta dicintai sehingga ibu dapat menghadapi masalah dengan baik. Jika seorang ibu yang sedang menyusui mendapat motivasi dari suami maka akan tercipta emosional ibu yang positif sehingga produksi hormon oksitosin meningkat. Hormon ini yang mempengaruhi produksi ASI sehingga kelancaran pemberian ASI dapat dilakukan lebih eksklusif [13]. Sehingga ibu senantiasa termotivasi memberikan ASI eksklusif kepada bayinya.

Motivasi seorang ibu sangat menentukan dalam pemberian ASI eksklusif. Rendahnya pemberian ASI eksklusif di kalangan ibu menyusui disebabkan karena kurangnya pengetahuan ibu tentang ASI eksklusif, tatalaksana rumah sakit yang salah, ketrampilan petugas kesehatan tentang cara pemberian informasi dan nasihat menyusui serta banyaknya ibu yang mempunyai pekerjaan di luar rumah. Disebutkan bahwa dorongan dan dukungan dari pemerintah, petugas kesehatan dan dukungan keluarga serta dari tempat ibu bekerja menjadi penentu timbulnya motivasi pada ibu menyusui [10]. Agar pemberian ASI secara eksklusif selama 6 bulan dapat tercapai secara maksimal, maka diperlukan pengetahuan dan motivasi dari seorang ibu. Ibu yang memiliki pengetahuan yang cukup dan memiliki motivasi maka akan senantiasa dan berusaha menyusui bayinya serta mengetahui apa yang bisa didapatkan dengan pemberian ASI kepada bayi sehingga akan berdampak pada timbulnya motivasi di dalam menyusui. Selain karena adanya pengetahuan tentang ASI, dukungan keluarga merupakan faktor eksternal yang paling berpengaruh terhadap keberhasilan ibu dalam memberikan ASI eksklusif. Adanya dukungan dari keluarga terutama dari suami maka akan berdampak kepada peningkatan rasa percaya diri atau motivasi ibu di dalam menyusui atau memberikan ASI eksklusif [10].

\section{Kesimpulan}

Simpulan penelitian dari literature review motivasi ibu dalam pemberian ASI eksklusif adalah sebagian besar responden berada pada tingkat motivasi tinggi. Semakin tinggi motivasi seorang ibu maka akan semakin tinggi pula ibu dalam memberikan ASI eksklusif pada bayinya.

Saran dalam penelitian literature review ini antara lain, perawat yang berada di pelayanan kesehatan maupun di komunitas setempat perlu melakukan penyuluhan pemberian informasi terkait dengan motivasi ibu dalam memberikan ASI eksklusif pada bayi. Serta tenaga kesehatan perlu memberikan dukungan kepada ibu menyusui agar motivasi tinggi ibu dalam memberikan ASI eksklusif tetap stabil. Dalam proses menyusui, seorang ibu perlu dukungan dari orang terdekat yaitu suami atau keluarganya. Karena dukungan tersebut dapat memotivasi ibu dalam memberikan ASI eksklusif selama 6 bulan. Tidak hanya sebuah dukungan saja, suami atau keluarga juga harus memberikan suasana yang nyaman bagi ibu menyusui agar motivasi ibu dalam memberikan ASI eksklusif tetap stabil.Literature Review ini juga sebagai dasar untuk melakukan penelitian lebih lanjut, khususnya mengenai motivasi pemberian ASI 


\section{Prosiding Seminar Nasional Kesehatan 2021 Lembaga Penelitian dan Pengabdian Masyarakat Universitas Muhammadiyah Pekajangan Pekalongan}

eksklusif. Diharapkan bagi peneliti selanjutnya yang ingin meneliti mengenai penelitian serupa agar dapat mengembangkan penelitian yang dilakukan oleh peneliti saat ini.

\section{Referensi}

[1] M. Adriani dan B. Wirjatmadi, Peranan Gizi Dalam Siklus Kehidupan, Jakarta: Prenadamedia Group, 2016.

[2] A. Amir, N. Nursalim dan W. A, "Faktor-Faktor yang Mempengaruhi Pemberian ASI pada Bayi Neonatal di RSIA Pertiwi Makasar," Media Gizi Pangan, vol. XXV, p. 47, 2018.

[3] R. Emah, "Dukungan Bidan Terhadap PemberianASI Eksklusif di Puskesmas Jamblang Kabupaten Cirebon Tahun 2020," Jurnal IImiah Indonesia, vol. V, pp. 274-275, 2020.

[4] Kemenkes RI, Profil Kesehatan Indonesia 2018 [Indonesia Health Profile 2018], Jakarta: Kementrian Kesehatan Republik Indonesia, 2019.

[5] R. M. Kusuma dan I. Aesti, "Motivasi Ibu Menyusui dalam Pemberian ASI EKsklusif di Puskesmas Tegalrejo Yogyakarta," Jurnal IImu Kebidanan, vol. V, pp. 49-58, 2018.

[6] E. D. Ratna dan K. E. Werdani, "Hubungan Pengetahuan dan Sikap dengan Motivasi Pemberian ASI Eksklusif Oleh Ibu Muda (Usia <20 tahun)," Jurnal IImu Kesehatan Masyarakat Berkala, vol. II, pp. 10-27, 2020.

[7] R. Harseni, "Hubungan Faktor Motivasi Ibu Terhadap Pemberian ASI Eksklusif di Puskesmas Lapai Kota Padang," Jurnal Bidan Komunitas, vol. II, 2019.

[8] E. Sulistyorini dan Fitriyani, "Motivasi Ibu Menyusui dalam Memberikan ASI Eksklusif di Posyandu Melati Desa Malangan Tanduk Ampel Boyolali Tahun 2011," 2011.

[9] H. Widuri, Cara Mengelola ASI Eksklusif Bagi Ibu Bekerja, Yogyakarta: G.Publishing, 2013.

[10] Srigati, J. Walean, Ahmil, W. L. Fitrianur dan V. U. Pangli, "Hubungan Pengetahuan dan Motivasi Ibu Terhadap Pemberian ASI Eksklusif di Desa Jono'oge," Jurnal Kesehatan Tadulako, pp. 58-67, 2016.

[11] Hesty, "Hubungan Pengetahuan dan Motivasi Ibu Tentang Pemberian Air Susu Ibu (ASI) Eksklusif di Kelurahan Paalmerah Wilayah Kerja Puskesmas Pal Merah di Kota Jambi," Jurnal Akademika Baiturrahim Jambi, vol. VII, 2018.

[12] N. Kusumayanti dan T. Nindya, "Hubungan Dukungan Suami dengan Pemberian ASI Eksklusif di Daerah Perdesaan," Jurnal Media Gizi Indonesia, vol. XII, 2018.

[13] I. Muninggar, "Hubungan Pengetahuan, Sikap, dan Dukungan Suami dengan Pemberian ASI Eksklusif di Wilayah Puskesmas Gambirsari Kota Surakarta," 2016. 